\title{
KERUSAKAN TUBE FURNACE AKIBAT DEPOSIT DAN KOROSI SULFIDA DI INDUSTRI MIGAS THE FAILURE OF FURNACE TUBE CAUSED BY DEPOSIT AND SULFIDE CORROSION IN MIGAS INDUSTRY
}

\author{
Laili Novita Sari \\ Balai Besar Teknologi Kekuatan Struktur - BPPT \\ Kawasan PUSPIPTEK Gd.220 Serpong, Tangerang 15314 \\ e-mail : laili.novita@gmail.com
}

Tanggal masuk naskah :03/03/2014; Tanggal revisi: 01/04/2014; Tanggal persetujuan cetak : 30/05/2014

\begin{abstract}
Abstrak
Pada saat Furnace 1 dan 2 dishutdown, kami melakukan kegiatan insitu metallografi pada tube furnace tersebut secara acak untuk menentukan ketahanannya (reliabilitasnya). Pada pemeriksaan tersebut diambil satu buah tube yang mengalami kerusakan yang berat untuk dianalisa penyebab kerusakannya sehingga dapat dilakukan tindakan penanggulangan untuk di kemudian hari. Pemeriksaan dan pengujian yang dilakukan terhadap tube Furnace 1 dan 2 , meliputi : pemeriksaan fraktografi dan metalografi, uji kekerasan, analisa komposisi kimia, serta pemeriksaan dengan SEM dan EDAX. Data dari hasil pemeriksaan dan pengujian tersebut kemudian di analisa untuk mengetahui penyebab kerusakan tube furnace tersebut. Dari hasil pengujian dapat disimpulkan bahwa tube nomer D29 furnace II coil 2 tidak mampu menerima panas berlebih dampak dari deposit sehingga pada permukaan diameter luar terbentuk grafit dan pada permukaan diameter dalam terserang korosi sulfidasi yang akibatnya terjadi penipisan ketebalan. Daerah penipisan dan daerah grafitisasi merupakan daerah yang kritis sehingga jika tube menerima beban statis dan temperatur berlebih maka mengalami kerusakan.
\end{abstract}

Kata kunci : tube furnace, over heating, korosi, deposit.

\begin{abstract}
When furnace 1 and 2 were shutdown, we did in situ metallography on furnace tube randomly to know its reliability. Tube which damage a failed tube was taken to laboratory to be analyed the failure cuased to avoid the same failure in the future. The examination and testing held on tube furnace 1 and 2 CDU III was : fractography and metallography examination, hardness testing, chemical composition analysis and SEM - EDX examination. From the examination and testing can be concluded that the tube furnace can not resist over heating as a result of deposit, graphite was formed in outer side and sulfide corrosion was formed in inner side causing diameter thinning. Depletion and graphitization region is a critical area so if the tube receives a static load and the excess temperature the tube will damage.
\end{abstract}

Keywords : tube furnace, over heating, corrosion, deposite

\section{PENDAHULUAN}

Pada saat plant dishutdown, dilakukan kegiatan insitu metallografi pada tube furnace tersebut secara acak untuk menentukan ketahanannya (reliabilitasnya). Pada pemeriksaan tersebut diambil satu buah tube yang mengalami kerusakan yang berat untuk dianalisa penyebab kerusakannya sehingga dapat dilakukan tindakan penanggulangan untuk di kemudian hari.

Adapun data teknis peralatan Furnace adalah sebagai berikut : 


\begin{abstract}
Material : ASTM A 213 Grade T22

Tekanan operasi $: 16 \mathrm{~kg} / \mathrm{cm}^{2}$

Temperatur operasi : $550^{\circ} \mathrm{C}$

Tube furnace tersebut dibawa ke laboratorium untuk dilakukan pemeriksaan dan pengujian, meliputi : pemeriksaan fraktografi dan metalografi, uji kekerasan, serta analisa komposisi kimia.
\end{abstract}

\section{BAHAN DAN METODA} meliputi :

Metoda pemeriksaan dan pengujian

\section{a. Pemeriksaan secara visual}

Pemeriksaan visual dilakukan untuk mengetahui karakteristik kerusakan dan menentukan langkah persiapan untuk pemeriksaan berikutnya.

\section{b. Pemeriksaan Makrografi}

Pemeriksaan makrografi dilakukan untuk mengetahui awal kerusakan dan perambatan kerusakan.

\section{c. Pemeriksaan mikrografi}

Pemeriksaan mikrografi dilakukan untuk pengamatan lebih detil pada daerah kerusakan seperti kondisi mikrostruktur, kerusakan struktur, dan lain - lain. Alat alat yang digunakan untuk pemeriksaan sebagai berikut :

-Alat pemotong

-Mesin gerinda dan poles

-Mikroskop

-Kamera Digital

\section{d. Komposisi kimia}

Untuk mengetahui unsur yang terkandung dalam tube furnace menggunakan spectrometer.

\section{e. Uji kekerasan}

Untuk mengetahui sifat mekanis material dari tube furnace dan dibandingkan dengan standar specifikasinya.

\section{f. Analisa SEM - EDX}

Analisa SEM - EDX dilakukan untuk mengamati kondisi dan unsur yang terkandung pada permukaan patahan.

\section{HASIL DAN PEMBAHASAN}

\subsection{PEMERIKSAAN FRAKTOGRAFI}

Secara visual terlihat adanya retakan- retakan pada bagian luar fire side tube furnace (lihat gambar 1 dan 2). Pada bagian luar terlihat banyaknya deposit pada daerah sekitar patahan dan pada bagian dalam terlihat adanya lapisan endapan yang tebal (lihat gambar 3). Pada gambar 3 menunjukkan terjadinya scale dan deposit melapisi bagian dalam pipa atau bagian luar pipa.

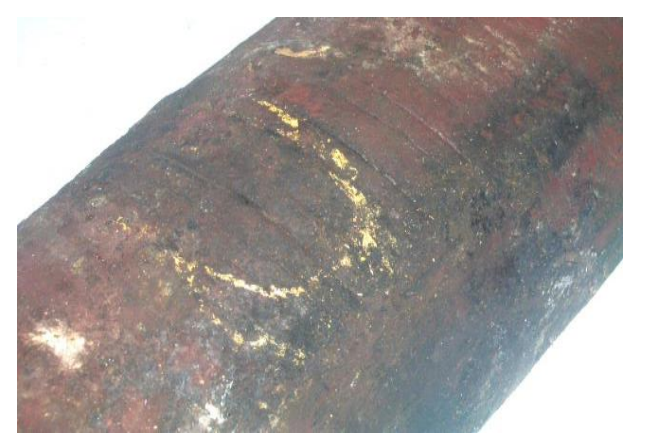

Gambar 1 : Tube furnace yang mengalami retakan.Terlihat terdapat beberapa retakan. Retakan berada pada arah jam 12 .

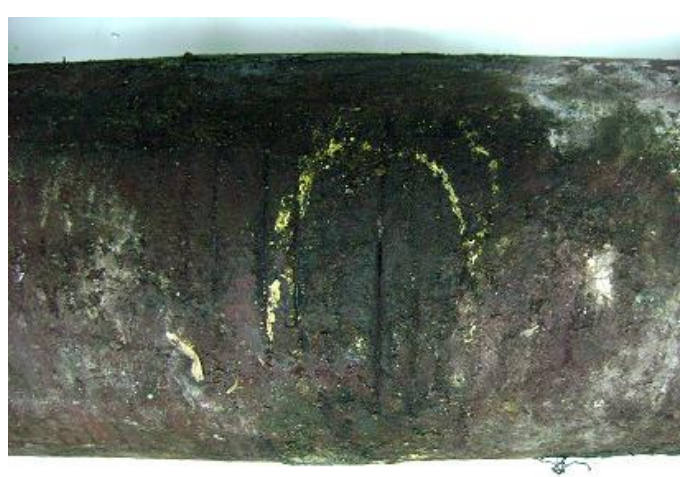

Gambar 2 : Terlihat banyak deposit pada daerah patahan.

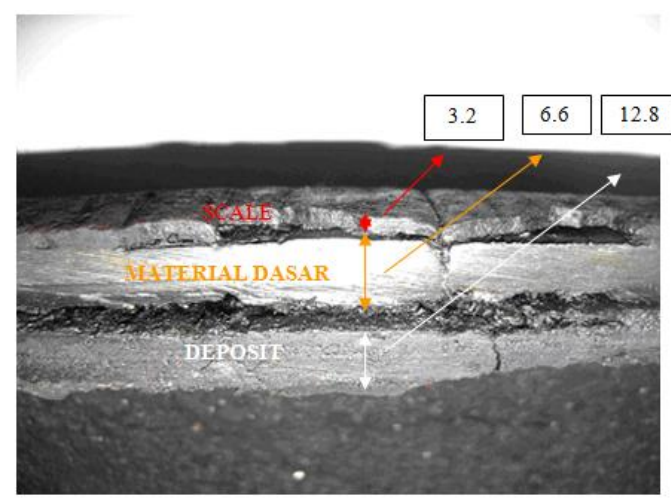

Gambar 3 : Terlihat retakan merambat menembus dari bagian dalam sampai bagian luar. 


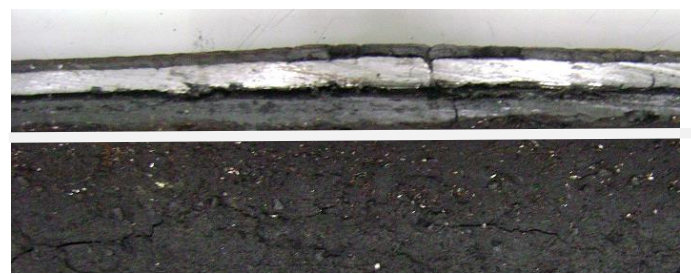

Gambar 4 : Daerah patahan terjadi bulging

Lokasi A yang merupakan lokasi yang jauh dari patahan berada pada fire side (arah jam 12) sedangkan lokasi B adalah lokasi yang jauh dari patahan berada pada wall side (arah jam 6). Dapat ditandai dari endapan pada gambar 6 menunjukkan tube furnace bagian A lebih tebal dibanding endapan pada bagian B.

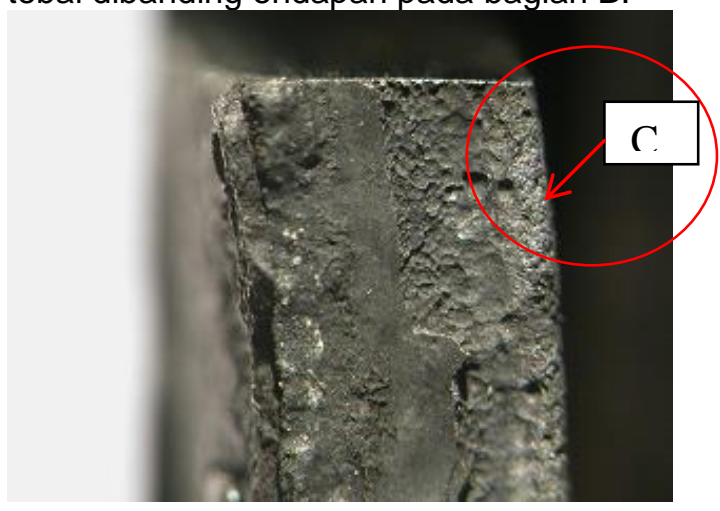

Gambar 5 : Permukahan patahan yang menunjukkan awal patahan.

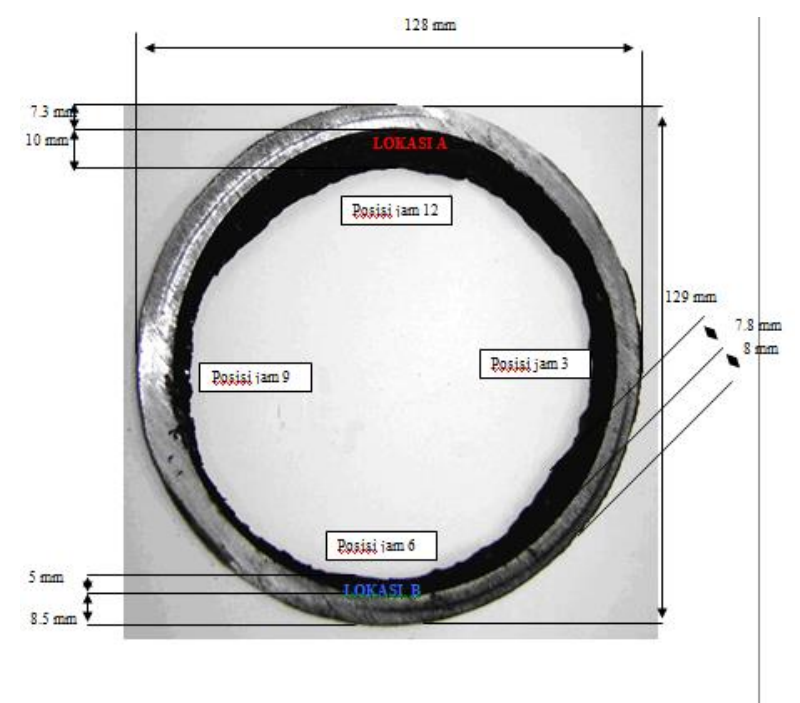

Gambar 6 : Penipisan tube terjadi pada jam 12 (fire side) dengan ketebalan $7.3 \mathrm{~mm}$ dan pada lokasi yang sama ketebalan karat sekitar 10 $\mathrm{mm}$.

\subsection{PEMERIKSAAN METALOGRAFI}

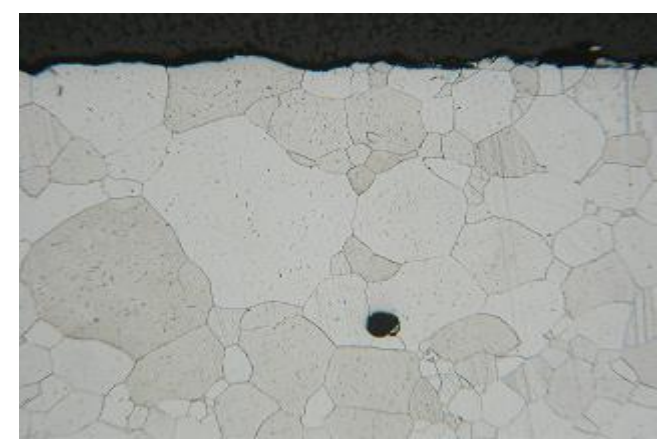

Gambar 7: Material pada lokasi A. Terlihat adanya graphitisasi yang sudah parah.

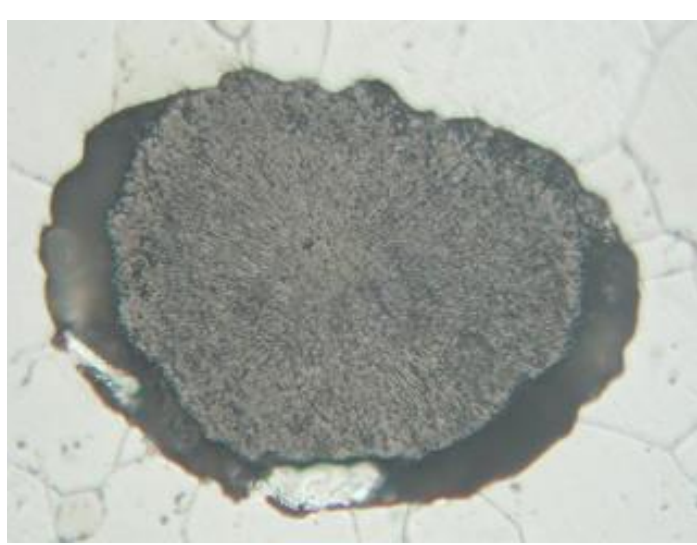

Gambar 8 : Microstruktur lokasi A. Terlihat adanya graphit. Mokrostruktur ferrite pearlit telah berubah menjadi ferritic.

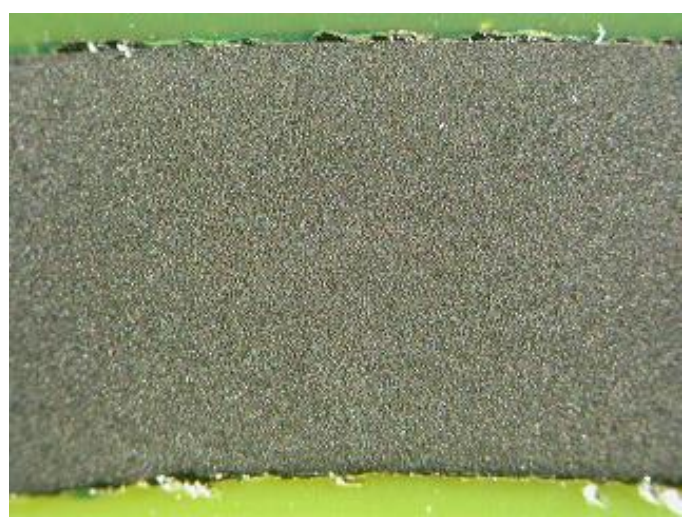

Gambar 9 : Foto penampang melintang lokasi B. Tidak terlihat perubahan besar butir. 


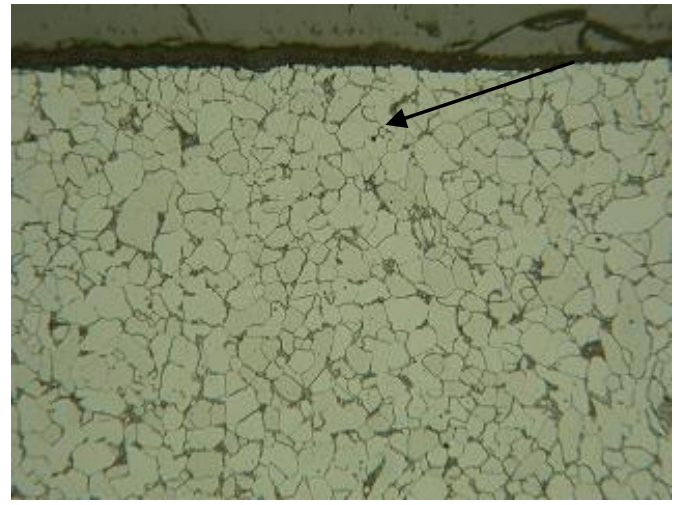

Gambar 10 : Material pada lokasi B. Bagian permukaan outside

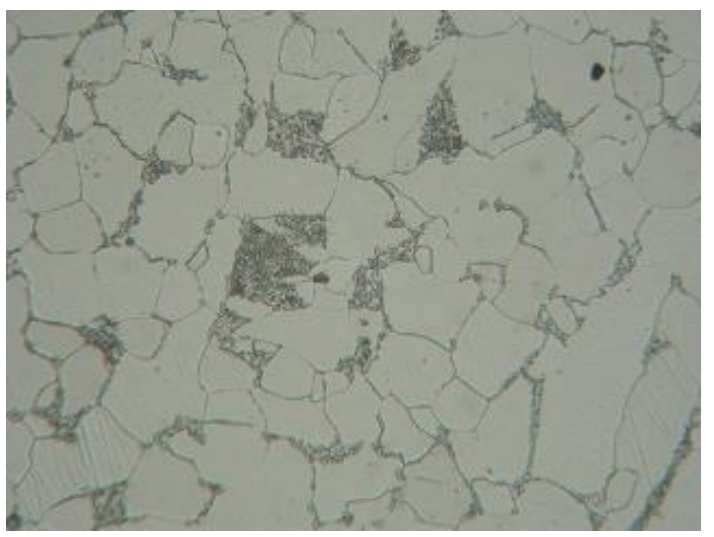

Gambar 11: Microstruktur lokasi B menunjukkan mikrostruktur ferrite pearlite.

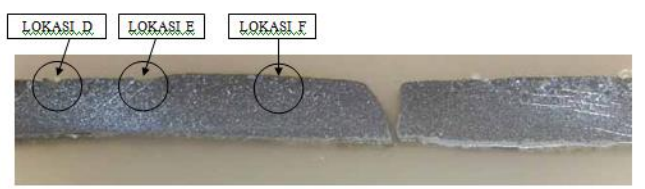

Gambar 12: Penampang memanjang dari patahan. Bentuk patahan telihat lebih lebar dibagian luar.

Terjadi perubahan besar butir pada lokasi A yang terletak pada fire side. Pada lokasi A juga terlihat bahwa grafit yang terbentuk lebih besar dan telah terjadi perubahan mikrostruktur menjadi ferritic dimana cementit dari stuktur ferrite pearlite berubah menjadi grafit (lihat gambar 7 dan 8). Pada lokasi B yang berada pada wall side tidak terjadi grafitisasi dan tidak mengalami perubahan mikrostruktur serta tidak mengalami perubahan besar butir ( lihat gambar 9-11). Terlihat banyak cacat permukaan ( lokasi D,E dan F) pada permukaan luar (fire side) material (lihat gambar 12). Pada daerah patahan tube furnace bagian dalam terlihat adanya korosi intergranular. Grafit yang terekspose ke permukaan dari dalam lekukan. Proses grafitisasi terjadi juga pada lekukan didaerah dekat patahan (lihat gambar 13 dan 14). Mikrostruktur di lokasi wall side patahan merupakan ferrite pearlite sedangkan pada fire side patahan cementite dari dalam struktur ferrite pearlite berubah menjadi graphite ( lihat gambar 13 - 18). Pada bagian wall side telah terjadi grafitisasi tahap awal ( lihat gambar 17).

Pada gambar 19 (a), (b) , (c) menunjukkan microstruktur telah terjadi grafitisasi dan pada gambar 19 (d) menunjukkan bahwa material mengalami korosi intergranular, pada gambar tersebut juga menunjukkan terjadinya perbesaran butir, dengan intensitas perbesaran paling besar dibagian luar.

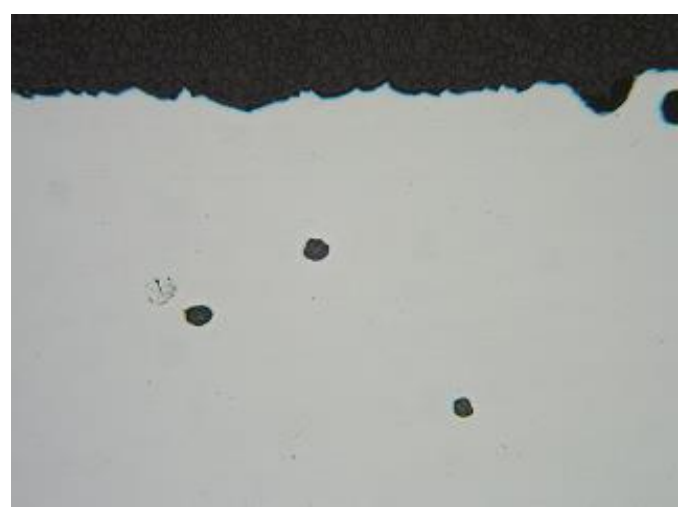

Gambar 13 : Pecahan dari tube furnace tanpa etsa. Terlihat adanya graphitisasi. Perbesaran : $50 \mathrm{x}$.

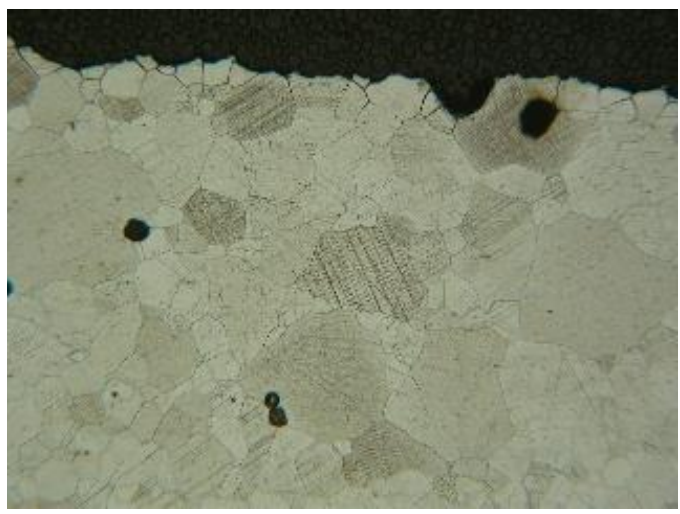

Gambar 14: Gambar 13 setelah dietsa. Terlihat adanya graphitisasi dan perubahan struktur mikro. Perbesaran : $50 \mathrm{x}$. 


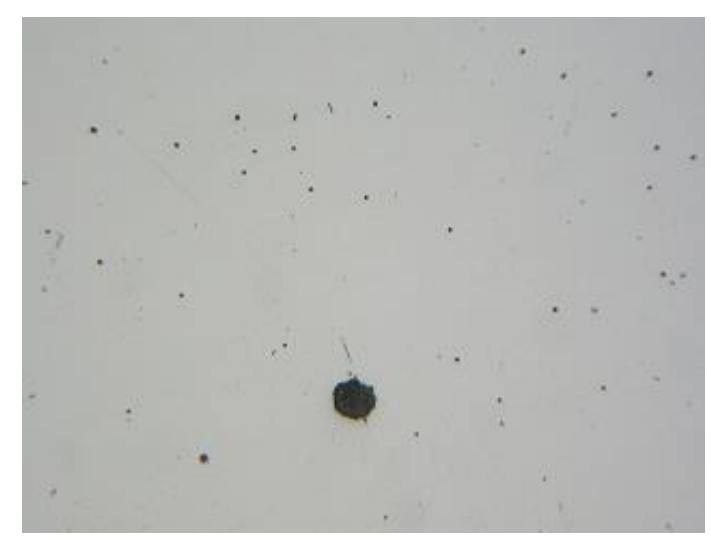

Gambar 15 : Foto tanpa etsa pada fire side patahan( arah jam 12). Terlihat grafitisasi yang banyak dan membesar.

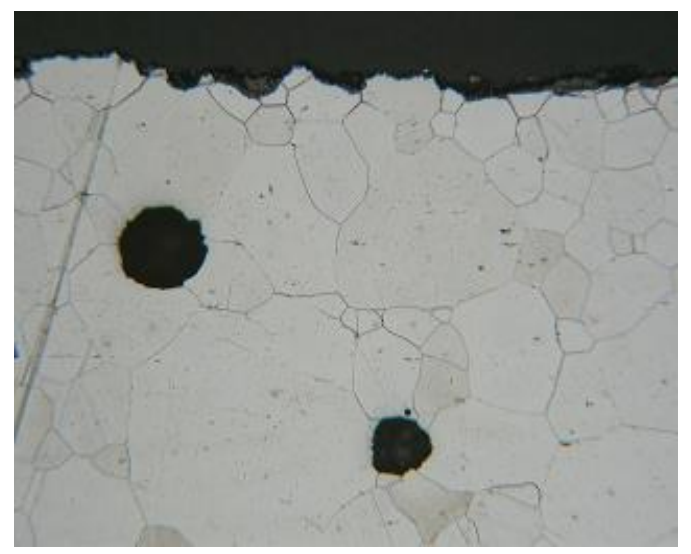

Gambar16 : Struktur mikro pada permukaan fire side patahan (arah jam 12)Terlihat grafitisasi yang banyak dan membesar.

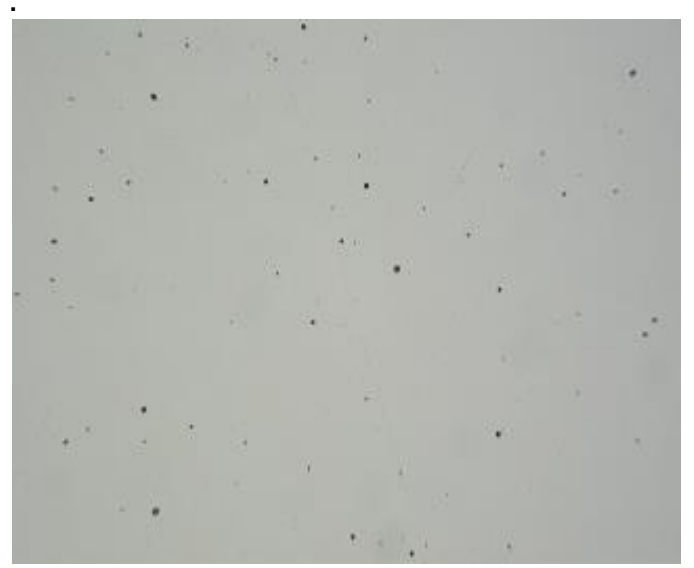

Gambar 17 : Foto nonetsa pada cool side patahan (arah jam 6).Terlihat adanya grafit yang menyebar tetapi belum membesar.
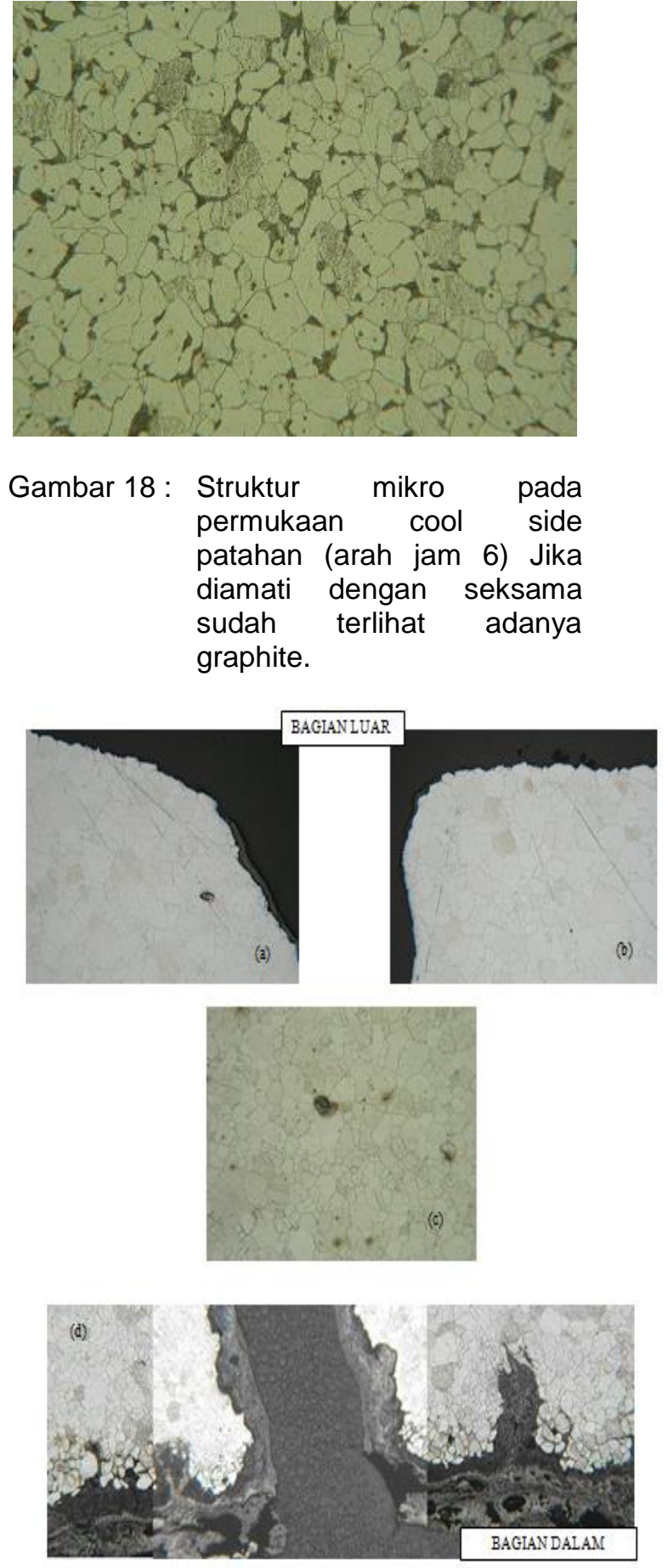

Gambar 19:

(a) Dan (b). Foto mikrostruktur kanan dan kiri bagian luar tube furnace yang mengalami patah. Pembesar $100 x$.

(c) Foto strukutur mikro bagian tengah tube furnace yang mengalami patah. Perbesaran $100 \mathrm{x}$.

(d) Foto struktur mikro bagian dalam tube furnace yang mengalami patah. Menunjukkan adanya korosi di permukaan. Perbesaran 100x. 


\subsection{PEMERIKSAAN KOMPOSISI KIMIA}

Dari hasil komposisi kimia diketahui bahwa material tidak sesuai dengan spesifikasi (ASTM A 213 Grade T22 ) dimana terdapat perbedaan yang besar pada unsur chromium dan molybdenum. Unsur Cr dari tube furnace adalah $0.018 \%$ sedang spesifikasi standar ASTM A 213 Grade T22 adalah 1.9 - $2.6 \%$; unsur Mo pada tube furnace adalah $0.0018 \%$ sedangkan standar ASTM A 213 Grade T22 adalah 0.87 - $1.13 \%$. Paduan Chromium dan Molybdenum diberikan untuk peningkatatan ketahanan terhadap panas dan korosi serta menghambat terbentuknya scale. Kekurangan cromium juga mempermudah terjadinya korosi sulfidasi.

Tabel 1 . Hasil uji komposisi kimia

\begin{tabular}{ccc}
\hline Unsur & $\begin{array}{c}\text { Result } \\
\text { (\%wt) }\end{array}$ & $\begin{array}{c}\text { ASTM A } \\
\text { 213 grade } \\
\text { T22 }\end{array}$ \\
\hline $\mathrm{Fe}$ & 99.18 & \\
\hline $\mathrm{C}$ & 0.13 & $0.05-0.15$ \\
\hline $\mathrm{Si}$ & 0.21 & Maks 0.50 \\
\hline $\mathrm{Mn}$ & 0.49 & $0.30-0.60$ \\
\hline $\mathrm{Cr}$ & 0.018 & $1.90-2.60$ \\
\hline $\mathrm{Ni}$ & 0.018 & \\
\hline $\mathrm{Mo}$ & 0.0018 & $0.87-1.13$ \\
\hline $\mathrm{Cu}$ & 0.0076 & \\
\hline $\mathrm{Al}$ & 0 & \\
\hline $\mathrm{V}$ & 0.011 & \\
\hline $\mathrm{W}$ & 0.066 & \\
\hline $\mathrm{Ti}$ & 0 & \\
\hline $\mathrm{Nb}$ & 0 & \\
\hline $\mathrm{B}$ & 0 & \\
\hline $\mathrm{S}$ & 0.028 & Maks 0.025 \\
\hline $\mathrm{P}$ & 0.0027 & Maks 0.025 \\
\hline & & \\
\hline
\end{tabular}

\subsection{UJI KEKERASAN}

Hasil uji kekerasan menunjukkan bahwa tube nomor D29 furnace II coil 2 CDU III memiliki kekerasan yang sesuai standar spesifikasi ASTM A 213 Grade T22 pada lokasi yang utuh dan jauh dari patahan sedang pada daerah dekat patahan cenderung lebih rendah dari standar yaitu dibawah $170 \mathrm{HV}$. Hal ini kemungkinan disebabkan bagian ini telah mengalami grafitisasi.

\subsection{PEMERIKSAAN SEM - EDX}

Hasil uji SEM tidak memperlihatkan alur kerusakan karena bagian tengah dari material meleleh. Patahan dengan sudut 45 derajat dapat dilihat pada hasil SEM tersebut yang mempertegas bahwa kerusakan berawal dari luar. Bentuk patahan di bagian luar lebih kasar sedangkan bagian dalam lebih halus (lihat gambar 20).

Hasil EDX kerak dalam menunjukkan adanya unsur agresif Clour, dan Sulfur ini menunjukkan bahwa kerak bagian dalam adalah deposit crude oil yang dapat menyebabkan karat atau korosi sulfidasi.

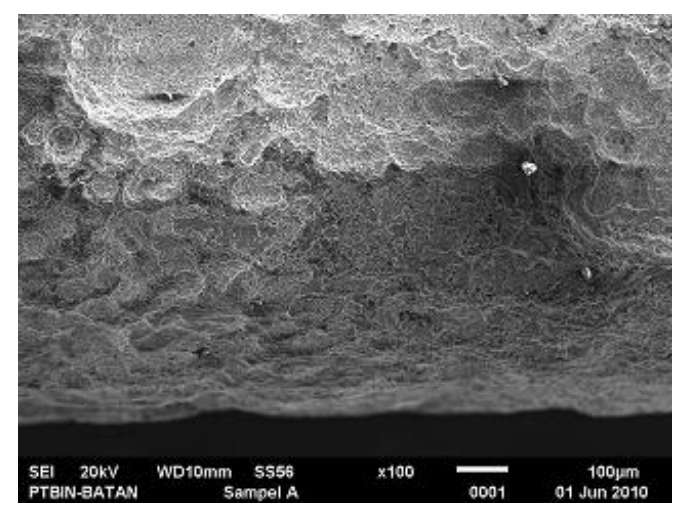

Gambar 20 : Gambar SEM bagian luar tube furnace. Perbesaran $30 \mathrm{x}$

Dari hasil uji kekerasan dan struktur mikro, bagian patahan memiliki kekerasan lebih rendah dibanding bagian lainnya karena terjadi proses grafitisasi. Grafitisasi menyebabkan material berkurang kekuatannya. Dengan grafit yang tumbuh sepanjang daerah ketebalan maka akan rentan terhadap pembebanan. Grafitisasi ini terjadi karena material tidak tahan terhadap suhu tinggi seperti standar A213 Grade 22. Selain gafitisasi juga terjadi pertumbuhan butir dan bulging serta scale yang berarti telah terjadi overheating pada material pipa. Pada permukaan metal terlihat adanya grafit yang terekspose dipermukaan menyebabkan beberapa lekukan yang melebar. Hasil EDX permukaan patahan tidak ditemukan unsur yang agresif melainkan unsur carbon yang 
sangat besar pada daerah dekat permukaan luar atau fire side.

Perbedaan temperatur yang besar antara bagian luar dengan bagian dalam dapat menyebabkan terjadinya korosi sulfidasi yang ditandai dengan adanya korosi intergranular dan hasil EDX pada deposit dalam ditemukan adanya sulfur yang cukup besar. Sulfidasi dapat menyebabkan penipisan material.

Deposit yang terbentuk didalam material dan scale yang terbentuk di bagian dalam menyebabkan panas tidak terdistribusi dengan baik dan over heating. Pengaruh permukaan material dan pengurangan dimensi serta overheating diduga merupakan faktor- faktor penting yang berperan dalam kerusakan pipa. Korosi sulfidasi dan grafitisasi dapat dihindarkan dengan menambahkan unsur chromium.

\section{KESIMPULAN}

Komposisi kimia pada tube berbeda dengan speksifikasi ASTM A 213 Grade T22,Struktur mikronya berupa ferit perlit dengan inklusi memanjang. Pada diameter luar tube terjadi perubahan struktur mikro dari ferit perlit ke ferit, dan telah terjadi grafit pada lokasi yang sama dan ada sebagian grafit yang berada pada dekat dengan permukaan luar sehingga membentuk sumuran. Pada diameter dalam juga terjadi perubahan struktur ke struktur ferit dan pada permukaan mengalami serangan korosi intergranular akibat sulfidasi, di beberapa lokasi terjadi laju korosi lebih tinggi yang ditunjukkan dengan penetrasi lebih kedalam.Telah tejadi bulging pada area patahan. Dari temuantemuan diatas dapat disimpulkan bahwa tube furnace tidak mampu menerima panas berlebih dampak dari deposit sehingga pada permukaan diameter luar terbentuk grafit dan pada permukaan diameter dalam terserang korosi sulfidasi yang akibatnya terjadi penipisan ketebalan. Pada area penipisan dari diameter dalam dan terbentuknya grafit pada permukaan luar pada posisi yang sama adalah bagian terkritis jika tube menerima beban statis dan temperatur berlebih yang akibatnya tube mengalami kerusakan.

\section{DAFTAR PUSTAKA}

1. Metal Handbook of ASM, "Failure Analysis and Prevention",vol 11,Ninth Edition,American Society for Metals,Ohio,1998.

2. Abbaschisn, Red-Hill, "Physical Metallurgy Principles", 4 th edition,2009.

3. Dowling, Norman E, "Mechanical behaviour of material ", 3 rd edition.2007.

4. Gasko Martin , Rosenberg Gejza, "Correlation between hardness and tensile properties in ultra high strength dual phase steel sort communication, Material Engineering 18. 2011. 155-159.

5. Hucinska Joanna, "Influence of sulphur on high temperature degradation of steel structure in the refinery Industry", Advaces In Materials Sciece vol 6, No 1(9), June 2006.

6. Fatemi Ali, Zouroufi Mehrdad, Fatigue Performance evaluation of forge versus competing maufacturing process technology: A Comparative Analytical and experimental study, AISI and FIERF. 2004.

7. Norsok Standard, Material Selection", Nourway, M001 Rev 4, August 2004.

8. Bush Dan, Brown Jeff, Lewis Keith, " an overview of NACE International Standard MR 0103 and Comparison with MR0175, Corrosion, lowa, 2004.

9. Zheng Fei Hu(2012)." HeatResistant steel, microstructure evolution and life assesment in power plant, thermal plant, $\mathrm{Dr}$ Muhammad Rasul (Ed, ISBN 978953-307-952-3,In tech availuablefrom

10. NACE International the corrosion society, NACE Corrosion Engineer's Reference Book, Third Edition, 2002. 
M.I. Mat. Konst. Vol. 14 No : 1 Juni 2014 : 1 - 7

11. Kucora istvan, Rovanovic Ljljana,

"Phyrolysis Furnace tube

damaging and inspection". ACTA

Technica corviniensis- Bulletine of

Engineering Fascicule 3, Tome

VII.2014. 